\title{
Comanagement of clams in Brazil: a framework to advance comparison
}

\author{
Ligia M. Rocha ${ }^{1}$ and Evelyn Pinkerton ${ }^{2}$
}

\begin{abstract}
In Brazil, the recognition that fisheries encompass both natural ecosystems and human well-being has increased, but initiatives are focused largely on highly-valued species, ignoring socially relevant resources such as Venus clams (Anomalocardia brasiliana). We investigate two initiatives involving comanagement of Venus clams in the past two decades: the Marine Extractive Reserve "Pirajubaé" and the "People of the Tides" project. We focus on the nature of the institutional arrangements, the involved groups (fishing communities and government), and the resource, as well as the steps involved in developing the partnerships, identifying which factors favor success in comanagement. Through these projects, fisherwomen got visibility and clam harvesters became the center of institutional developments. However, their rights in management will not become meaningful unless comanagement in protected areas is fully implemented, and government becomes more willing to share power in harvest planning, and to improve health, infrastructure, and the return of value to fisher families. Only then would such cooperation promote sustainability for Venus clams and fisher families.

RESUMEN. Los invertebrados marinos bentónicos son una fuente de alimentos e ingresos para los pescadores artesanales de América Latina. Sin embargo, todavía hay relativamente escasas investigaciones sobre la gestión de estos recursos. Si bien el reconocimiento de la pesca como un sistema marino socio-ecológico ha aumentado en la última década en Brasil, las iniciativas se han centrado en gran medida tanto en especies de alto valor como recursos sobreexplotadas, dedicando escasos esfuerzos a moluscos bivalvos socialmente relevantes como la Almeja venus (Anomalocardia brasiliana). En este trabajo se investigaron dos iniciativas brasileñas que involucran al co-manejo de la Almeja venus en las últimas dos décadas: la primera Reserva de Extracción Marina (REM) de Pirajubaé y el proyecto "People of the Tides". Basamos nuestro trabajo en el análisis de las condiciones que favorecen el éxito del co-manejo, incluyendo el marco institucional gubernamental, los recursos marinos y las comunidades pesqueras involucradas. Nuestros resultados muestran que si bien los recursos sedentarios como las almejas pueden favorecer las iniciativas de co-manejo, alcanzar el éxito no resulta una tarea fácil de alcanzar. El papel de las mujeres pescadoras ha sido reconocido y los pescadores se han convertido en el centro de las actividades, pero sus derechos en la gestión de los recursos marinos serán reconocidos una vez que las áreas marinas protegidas se implementen de forma plena, el gobierno tenga una mayor implicación y disponibilidad de compartir el poder, las actividades de extracción y sus actividades relacionadas sean incluidas y las familias de los pescadores obtengan beneficios tangibles. Sólo entonces las iniciativas de cooperación para promover la sostenibilidad de este molusco bivalvo tendrán éxito.
\end{abstract}

Key Words: artisanal fisheries; clams; comanagement; fisherwomen; marine protected areas; shell fisheries

\section{INTRODUCTION: A CONTEXT IN SEARCH OF A THEORY}

Marine benthic invertebrates are a major source of food, employment, and income to artisanal fishers in Latin America (Castilla and Defeo 2001). Women in particular collect shellfish, especially clams (Faustino 2008), as important food and source of low but reliable income (FAO 2007). Despite such widespread use, however, there is still relatively little research on shellfish management (Defeo and Castilla 2005). Experiences in Chile, Argentina, Canada, and Spain show that innovative cooperation between governments and shellfish users is key to better management and improvement of fisher livelihoods (Castilla and Defeo 2001, Frangoudes et al. 2008, Pinkerton and John 2008). To understand past initiatives, as well as to learn from experience and to evolve in a changing governance context (Ratner et al. 2012), it is useful to identify conditions that favor successful initiatives in comanaging natural resources (Pinkerton 1989, 2009a, Ostrom 2009) and challenges to be addressed (Nielsen et al. 2004).

In Brazil, the recognition that fisheries encompass both natural ecosystems and human well-being has increased in the past decade and participatory initiatives have taken place in the Amazon and along the coast (Seixas et al. 2011). These management initiatives have focused largely on highly valued species (Vasconcellos et al.
2007), ignoring socially relevant mollusks such as the tiny Venus clam (Anomalocardia brasiliana, Gmelin 1791), a common but important source of food and income to fishing communities on the Northeastern coast (Nishida et al. 2006).

Landing statistics for Venus clam are rare and total annual catch may vary from hundreds of tonnes (Rocha 2013) to thousands (Barletta and Costa 2009). Moreover, some stocks are declining because of coastal environmental deterioration and unregulated harvest (Pezzuto and Echternacht 1999, Nishida et al. 2004, SilvaCavalcanti and Costa 2009), following a pattern of stock depletion recognized in Guadalupe (Moueza et al. 1999) and in Latin America for general benthic shellfish stocks (Castilla and Defeo 2001). Echoing a global concern regarding marine resources conservation, Brazil has expanded its protected areas system (Prates and Blanc 2007). Marine protected areas ranging from "no-take zones" to multiple use have precipitated many conflicts between artisanal fishers and protected areas managers because of their impact on the livelihood, culture, and survival of artisanal fishing coastal communities (Diegues 2008, Lopes et al. 2013).

Despite the importance of Venus clams and protected areas, only two experiences involving clam comanagement have occurred in Brazil: (1) the first marine extractive reserve (MER) "Pirajubaé"

${ }^{1}$ Federal University of Rio Grande do Norte, Graduate Program in Ecology, ${ }^{2}$ Simon Fraser University, School of Resource and Environmental Management 
in the 1990s, and (2) the "People of the Tides" project (PoT), implemented from 2008 to 2011 . In the two decades between these initiatives, major changes occurred in Brazil: the national protected area system was established, and the legal framework for fisheries was improved with a Fisheries Act and a new federal agency, the Ministry for Fisheries and Aquaculture (MPA). Participatory management initiatives also flourished, from partnerships between government and NGOs to manage protected areas (Rocha and Jacobson 1998) to comanagement initiatives in fisheries (de Castro and McGrath 2003, Oviedo and Bursztyn 2004, Kalikoski et al. 2009, Seixas and Kalikoski 2009). Considering (a) the need to manage an important resource for fishing communities, (b) the institutional enhancements achieved in Brazilian fisheries, and (c) the experience acquired from clam management initiatives, an improved scenario for clam management can be envisioned. We analyze the steps achieved in the clam management initiatives in the two-decade time frame, discuss the barriers still to be overcome, and the steps needed to further advance comanagement in Brazil. This analysis also contributes to the international discussion of participatory resource management and calls attention to: clams, a resource seldom well managed; shell fisherwomen, traditionally marginal actors in fisheries; and comanagement activities involving harvesting as well as other activities and arrangements to better manage clams and improve fishers' quality of life.

\section{METHODS}

To analyze the two comanagement initiatives we focused on three aspects: (1) the institutional arrangements for power sharing between fisher organizations/communities and government agencies, (2) favorable conditions in the nature of clams, communities, and government agencies, and (3) the appropriate steps to implement partnerships. The analysis of institutional arrangements includes the scope and scale of management activities, as well as the number of parties and the level and type of rights exercised. The analysis of favorable conditions considers the literature on what sets of conditions in the resource, the communities, and the government agency partners are associated with successful comanagement in other cases. The analysis of appropriate steps focuses on the process of establishing a relationship among partners, as they progress from negotiation to the definition, establishment, and institutionalization of an agreement. These dimensions illuminate the complex nature of comanagement (Pinkerton 1989, 1992, 2003, 2009a, b, Pinkerton and Weinstein 1995, Agrawal 2002, Pinkerton and John 2008) and also fit what Jentoft and Chuenpagdee (2009) call a "governing system," the "system-to-be-governed," and "system of a governing interaction." Examining these three aspects allows us to better understand the variables and properties of the dynamic comanagement processes over time, and therefore to identify priorities for clam fisheries.

Data from MER Pirajubaé was extracted from literature (von Behr 1995, IBAMA 1996, 2003, 2004, 2005, Pezzuto and Echternacht 1999, Souza 2007, Pezzuto et al. 2010, Vizinho and Tognella-de-Rosa 2010, Spínola 2011). Spínola (2011) was a particularly important source because she discusses in detail fisher participation in Pirajubaé. Information about the "People of the Tides" project was based on project reports (Brasil ABC/MRE 2007, WFT and MPA 2011), and the first author's firsthand experience. The first author became a local partner of PoT when project implementation in the State of Rio Grande do Norte involved a reserve (Ponta do Tubarão) where she was conducting research with clam harvesters. During PoT implementation she paid monthly visits to the reserve (fieldwork was partially funded by PoT), started a participatory monitoring for the clam fisheries project, and attended most local and regional PoT events. She also acted as: (a) a witness to PoT development, (b) a bridge between PoT coordination and shell fisher families, and (c) an advocate for PoT and fisher families. Before working as a PoT local partner, she helped to implement the Reserve Management Council. Her eight years in the area allowed the first author to establish rapport and trust with fisher families, local leaders, and the state agency, which resulted in a high level of confidence in the findings. The second author, in collaboration with the first author, was then able to apply a theoretical framework developed from three decades of studying comanagement arrangements around the world, and clam fisheries in particular (Pinkerton and John 2008).

\section{Case study 1: Pirajubaé, Brazil's first marine extractive reserve (MER).}

The Brazilian Extractive Reserve is a type of protected area that allows people to live and keep their traditional livelihoods within the area, as long as it is considered sustainable. Such reserves are designed to be managed collaboratively by both government and local people (Fearnside 1989, Lopes et al. 2011). Although the success of extractive reserves is ambiguous (Goeschl and Igliori 2004), MER has become the most frequent type of protected area addressing coastal artisanal fisheries in Brazil. MER Pirajubaé was created in 1992 in the State of Santa Catarina (Fig. 1) to manage the harvest of $A$. brasiliana by traditional fisher families. After the introduction of hand dredges to increase production up to a commercial scale, the federal government implemented a pilot project for clam management in 1988. Following initial success, fisher families and the regional office of the Brazilian Institute for Environment and Renewable Natural Resources (IBAMA) pushed the national office to create a MER and regulate clam extraction. Fishers created their own association (1995) and won legal support to harvest (1996), when the jointly developed use plan was released. However, in the same year IBAMA allowed road construction to improve access to the regional airport, with the condition of monitoring clam stocks to access its potential impact. The road damaged $41 \%$ of MER's mollusk beds. Fish stocks plummeted, and Venus clam became overexploited. The fishers' association denounced the damage to no avail and in 1997 IBAMA banned clam harvesting, turning traditional fishing into an illegal activity in a reserve created for such fisheries. Weak enforcement and low legitimacy kept fisheries exploited as an open-access resource. After five years, the Federal Public Prosecutor launched a public civil action against IBAMA and the state government over the road construction. In 2004 and 2005 IBAMA published new sets of rules for clam harvest with limited fisher participation; two years later there were signs of clam overexploitation.

A new phase for participation started in 2008 with two partnerships and MER improvement. Researchers at Vale do Itajaí University (UNIVALI) started a program of participatory governance to develop capacity for those involved in Pirajubaé, and the UN Development Program supported participatory management planning. Improvements in MER included a better 
skilled manager, new employees, and better work logistics. The manager, fishers, and researchers started a working group to discuss MER governance that ended up rebuilding the fisher organization. As a result, a multiparty management council with a fishers' majority and biannual elections was created in 2011 to collectively deliberate on MER. Harvest at Pirajubaé is still not sustainable, although additional agreements on clam management are likely to be negotiated and enacted in future.

Fig. 1. Location of Brazil's two experiences in comanagement of Venus clam (Anomalocardia brasiliana): "People of the Tides" project (PoT), in the states of Rio Grande do Norte (RN), Pernambuco (PE), Bahia (BA) and Paraíba (PB), and the Marine Extractive Reserve (MER) of Pirajubaé, in the state of Santa Catarina (SC).

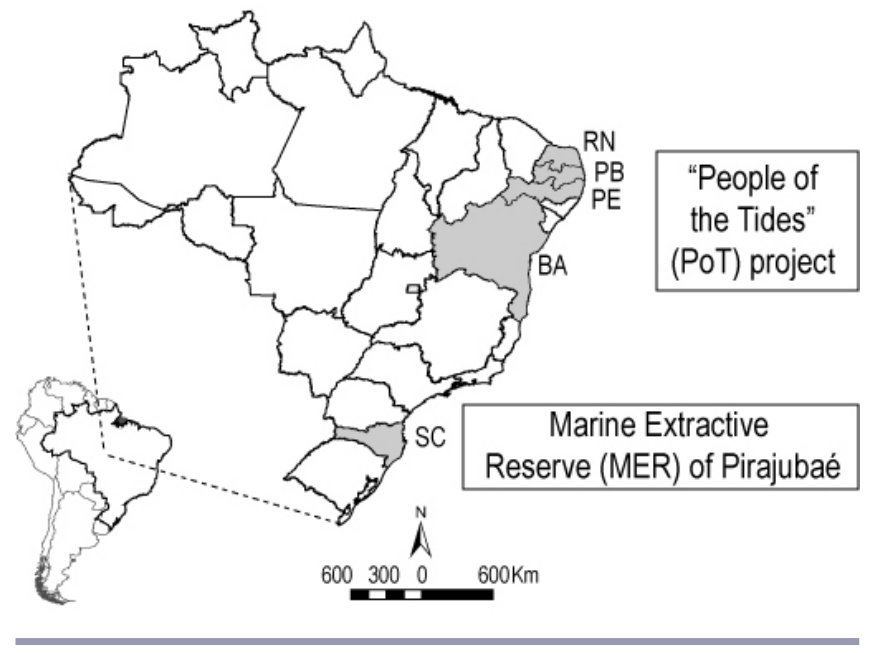

Case study 2: "People of the Tides" project (PoT)

During "People of the Tides" (PoT) project implementation (2009) the fisheries portfolio moved from IBAMA to the Brazilian Fishery and Aquaculture Ministry (MPA). PoT was an international partnership among the Canadian International Development Agency (CIDA), MPA, and the World Fisheries Trust (WFT). It built on two previous international partnerships funded by CIDA ("Shellfish Technology Transfer" and "Brazilian Mariculture Linkage" Programs). PoT's main objective was to promote capacity building and interinstitutional linkages among organizations engaged in projects to improve the quality of life in communities that directly depend on mollusk harvest. It provided tools, training, and networking opportunities to build capacity and engagement among existing projects working with shell fisher families, especially fisherwomen in the states of Bahia, Pernambuco, Rio Grande do Norte, and Paraíba (Fig. 1).

Bureaucratic processes from both countries limited PoT's implementation to two and a half years (from 2008 to 2011) instead of four. With this time constraint PoT's positive results were: (a) the recognition of fisher women's role in clam fisheries, (b) capacity building for partners, (c) a better understanding of existing value chains, (d) the creation of two networks involving shell fisher families (in the states of Bahia and Rio Grande do Norte), (e) clam seed production in labs, (f) governmental recognition of work-related injury and illness due to clam harvest, and $(\mathrm{g})$ peer-to-peer learning and knowledge transfer through exchanges of fishers and researchers.

\section{COMPARATIVE ANALYSIS OF BRAZILIAN CLAM COMANAGEMENT INITIATIVES}

The nature of institutional arrangements

The institutional arrangements at Pirajubaé and PoT are detailed in Table 1. The scope at MER Pirajubaé was narrow, specifically focused on harvest sustainability of Venus clams by one artisanal fishing community at the local level. Thus it operated at a very small geographic scale and scope and with few parties. In contrast, PoT was conceived at a national scale and involved a broad scope with multiparty arrangements. In PoT, fisher women also demanded a larger scope: the inclusion of occupational health issues, better access to social security rights, and improvements in the value chain. The scope of management activities varied according to place and time.

At Pirajubaé the initial phase focused on institution building (MER creation). This was followed by conflicts and loss of legitimacy. Fisheries collapsed and rules had low compliance. After 2008 a more participatory phase started including new partnerships, capacity building in governance, and the creation of a management council with a fisher majority (see Table 1 for details). With a focus on community development and faster implementation (less than three years), PoT included several activities promoting equity, capacity building, and networks, among others (Table 1). Positive results in seed production were achieved, building the path of replenishing mollusk beds in overexploited clam areas.

Regarding community rights and duties in Brazilian fisheries, sharing power is not common, but fishers at Pirajubaé actively participated in the creation of MER. By contrast, PoT was planned at the national level, as an international partnership, without including fishers in policy making at the beginning. However, during implementation this condition switched: participation became uncommon at Pirajubaé, while at PoT fishers could identify the project's strengths and weaknesses and participate in local and regional levels of decision making.

Legally, MER's artisanal fishers are comanagers: they have the right to participate in decision making as long as their practices are sustainable and follow conservation objectives. Nevertheless, the protected areas involved in both cases were not fully implemented, because of lack of infrastructure, human and financial resources, etc., and the rights were not enforced. In Pirajubaé the government kept a centralized approach for 15 years, but a new scenario is expected after the creation of the management council to rule the MER. PoT's activities fulfilled in part fishers' right to capacity development. Participating in harvest monitoring (only available at the reserve "Ponta do Tubarão," Rio Grande do Norte) also allowed fishers the right to collect their own information. In PoT and Pirajubaé, though, there is no clear information on whether benefits to fisher families were optimized by an increase in product quality or diversity. The recent capacity building at Pirajubaé and PoT initiatives probably needed more time to allow changes, and fishers needed more organizational skills to collectively solve problems such as getting a good price for their clams. 
Table 1. Comparison of institutional arrangements of clam comanagement initiatives in Marine Extractive Reserve Pirajubaé and "People of the Tides" project in Brazil.

\begin{tabular}{ll}
\hline \hline MER Pirajubaé \\
\hline Scope & Initial: To promote sustainable harvest of Venus clams \\
& (Anomalocardia brasiliana) and other natural resources by \\
& artisanal fishing community. \\
& Recent: Implement the participatory governance and promote \\
& conservation and sustainable use of other natural resources.
\end{tabular}

"People of the Tides" (PoT) project

To promote equity and poverty reduction through interinstitutional cooperation and capacity building. Initial scope: equity (better income generation and opportunities), community organization for sustainable production of mollusks, knowledge transfer, mollusk cultivation, and depuration systems. Enlarged scope: better recognition of labor-related illnesses, access to social security rights, and better access to a more organized value chain.

Scale Small: one state, one protected area, one coastal community (50 - 100 families), two mollusk beds in a shoreline of $6 \mathrm{~km}$.

Large: 4 states in the northeast coast, 5 protected areas (including another federal MER and four state areas for sustainable use), several communities and mollusk beds, $1646 \mathrm{~km}$ of shoreline. More than 1300 families.

Parties Few: IBAMA, fishers and their association, UNIVALI Many: Several government organizations and NGOs from national to University, and UNDP. With the management council (2011) local levels, artisanal fishing communities ( $>20)$, international parties became: fishers and their association (10 shell fishers, 4 funding agency (CIDA), universities, fisherwomen (1300), and others), government agencies (7), traditional people other than fishers (6), university, and resident associations (2).

Management Phase 1 (1992-1996): "Institutional building." Fisher Activities association creation, codefinition of a use plan with specific harvest rules (fishing effort, gear, minimum size, and rotational system in time and space).

Phase 2 (1996-2008): "Conflicts and discredit." Imposed fishing ban due to stock depletion (without surveillance). Very low participation on harvest rules.

Phase 3 (2008-actual): "Participatory governance.” Inclusion of new partners (university and UNDP), local capacity building (on participatory governance for fishers, MER manager, and researchers), MER improvement (more experienced manager and employees with better work logistics), creation of working group (fisher, manager, researchers) to discuss governance, resource users identification, and creation of a Management Council.

Management By law: In MERs fishers are comanagers: have the right to Rights and participate in decision making (to define priorities, to create Duties and enforce rules, to limit access of nonmembers of their community, to manage harvest timing for optimum product value). Practices must be sustainable, follow conservation objectives, and be approved by the environmental governmental agency.

In Pirajubaé: Rights enforcement varied over time. Fishers participated in the beginning, but the open access context after the road impact favored free riders, damaging rules acceptance and fishers' organization. Government ruled the MER most of the time. Management Council (2010) with fishers' majority reaffirmed fishers' rights. There is no information on whether MER maximized benefits to fishermen (increase in product price, productivity or supply management). aquaculture company.

Capacity building through workshops (on comanagement, gender, occupational health, biology of mollusk, economic feasibility studies for clam value chains), technical visiting, and exchange program (including international technical exchanges and regional peer-to-peer learning exchanges between community associations).

Equity: Activities involved fisher families with specific focus on women (1300 women and 680 men from local communities, government, and NGOs).

Recognition of occupational health problems due to harvesting: Publishing a booklet and developing the "Interstate Coalition Initiative for addressing occupational health and social rights of fisherwomen."

Support for democratic governance and economic feasibility studies for artisanal mollusk fisheries (30 people, $50 \%$ women) and creation of fisher networks. Support for fisheries research and clam seed production.

Initial planning with key players (with long experience working with fishers). Fishers participated more actively during project implementation, most of the time through involvement in workshops and exchange activities, fulfilling their right to capacity development. In general fishers gave their input about their needs and priorities and opinions about adequacy of previous planned activities. Local actors also identified projects' strengths and weaknesses, helped to monitor project development and participated in two levels of decision making: the working groups and the national council.

The right to exclude others existed inside the protected areas (PAs), but it was not enforced. The right to coordinate own activities, solve problems, and manage harvest timing for optimum product value were not implemented. In Rio Grande do Norte fisher families monitored their harvest (at "Ponta do Tubarão" Sustainable Development Reserve") and in Bahia they also started attempts to get a special license for oyster production (exclusive access).

\section{The nature of the resource}

The nature of the resource plays a significant role in the institutional sustainability of common pool resources (Agrawal 2002) and in the success of comanagement initiatives (Pinkerton $2009 a$ ). These authors argue that mobility, riskiness of flow, boundary clarity, visibility, spoilability, scarcity and value, cultural salience, and resource size are characteristics that influence the success of a sustainable management initiative.

Shellfish harvesting occurs along Brazil's entire $8000 \mathrm{~km}$ coastline and is one of the most accessible food sources for coastal 
Table 2. Clam fisher characteristics at Marine Extractive Reserve (MER) Pirajubaé and some communities involved in "People of the Tides" (PoT).

\begin{tabular}{|c|c|c|}
\hline Clam Fisheries & MER Pirajubaé & PoT \\
\hline Gender & Mainly men ${ }^{\dagger, \uparrow}$ & Mainly Women ${ }^{\ddagger},, \mid, 6$ \\
\hline Fisher's age & 41 to $51 \mathrm{yo}^{\bullet}$ & $32-38$ yo \\
\hline Formal education & $\begin{array}{l}4 \% \text { - illiterate } 53 \% \text { - up to } 4 \text { years } 35 \% \text { up to } 8 \\
\text { years }\end{array}$ & $\begin{array}{l}25 \% \text { to } 37 \% \text { - illiterate }{ }^{\ddagger} 41 \% \text { to } 61 \% \text { up to } 4 \text { years } 2 \% \text { to } 9 \% \text { up } \\
\text { to } 8 \text { years }\end{array}$ \\
\hline Household size & 3 to $4^{\pi}$ & $5^{\dagger, \S}$ \\
\hline $\begin{array}{l}\text { Annual catch ton (Year) } \\
\text { (Location) }{ }^{\dagger \dagger}\end{array}$ & 947 (2005) (MER Pirajubaé) $\dagger$ & $\begin{array}{l}440 \text { (2010) (Ponta do Tubarão Estuary, Rio Grande do } \\
\text { Norte }^{\#) ; ~} 3000 \text { (2005) (Goiania Estuary, Pernambuco§) }\end{array}$ \\
\hline Clam stock status ${ }^{\dagger \dagger}$ & Decreasing abundance ${ }^{\dagger, \pi}$ and size $\dagger$ & Decreasing abundance $e^{\ddagger, \#}$ \\
\hline Clam meat price US\$/kg (year) & $2.3(2005)^{\dagger}$ & $\begin{array}{l}0.4 \text { to } 1.5(2009)^{\prime} \\
2.0 \text { to } 3.5(2010)^{\#}\end{array}$ \\
\hline Income & Not available & Less than one Brazilian monthly minimum wage ${ }^{\star * \#}$ \\
\hline Fuel & Wood from mangrove or community & Wood from mangrove or community ${ }^{\text {l, } \#}$ \\
\hline
\end{tabular}

†Souza (2007), †Nishida et al. (2008), §Barletta and Costa (2009), Silva-Cavalcanti and Costa (2009), ${ }^{\circledR}$ Vizinho and Tognella-de-Rosa (2010),

${ }^{\#}$ Rocha (2013).

${ }^{\dagger \dagger}$ Data on catches and stock status are scarce and, when available, are time and site specific.

communities in the northeast (Macnaughton et al. 2010). The Venus clam has a small shell $(15-30 \mathrm{~mm})$, little mobility, and patchy distribution. Clam habitat boundaries are especially clear inside estuaries, where the tide level at specific times defines sandy mudflats accessible for harvesting. Visibility depends on flats location: when fronting fishing communities, clear visibility of mollusk beds helps management enforcement; more distant flats may be "invisible," because of mangrove mosaic inside estuaries, and more difficult to patrol. Clams are culturally salient, given their importance for food and income generation. Venus clams also have characteristics less favorable to management: low market value (up to US\$ $3.5 / \mathrm{kg}$ clam meat), low storage capacity, and high fluctuation in abundance (Monti et al. 1991). Overall, however, the above characteristics favor comanagement.

\section{The nature of fishing communities}

It is estimated that at least 50,000 people live exclusively from clams and oysters in the northeast coast (Brasil ABC/MRE 2007). Despite such social importance, there is no reliable socioeconomic information for coastal artisanal fisheries in Brazil (Vasconcellos et al. 2011). Statistics are especially weak for fisherwomen whose fisheries may be considered as household duties. This is particularly significant for clam management on the northeast coast because harvesters are mainly women. Specific studies in Pirajubaé and communities involved in PoT are presented in Table 2. Shell fishers are old and have low educational levels (Table 2), a profile similar to general artisanal fisheries in Brazil (Vasconcellos et al. 2011). Total annual catches vary in hundreds of tonnes, but with low market value and strong dependence on middlemen, families have low annual incomes (generally less than one Brazilian average monthly minimum wage). Families depend on fuel wood to process clams, middlemen to access markets, and government social programs to supplement income. Frequent strategies to deal with decreasing stock and low income are searching for new mollusk beds, diversification of activities, enrollment in social programs, or leaving the activity (Souza 2007, Nishida et al. 2008, Rocha 2013).

In general, fishing communities show low levels of organization because they have suffered political and socioeconomic marginalization for decades. A top-down policy for national security after World War I imposed a system of fisher organization ("colônia") to register and control fishers and vessels along the coast (Silva 1988). Colônias in general often became controlled by local elites who frequently did not represent artisanal fishers' interests (Seixas 2006), and certainly not those of fisherwomen, who have historically struggled for their recognition as fishers (Articulação Nacional de Pescadoras 2006). Despite this context, Catholic organizations, NGOs, and governmental programs have supported community organizations and women's participation in the past decades (Vasconcellos et al. 2011). PoT, for example, included three colonias in northern Pernambuco led by women involved with clam harvesting, who were strong political leaders (A. Macnaughton, PoT coordinator, personal communication).

Along the coast, fishing communities are internally diverse; they have different cultural backgrounds and livelihoods (Vasconcellos et al. 2007). However, shell fisher women are generally concerned about community infrastructure. They cannot harvest if they have to stay home caring for someone who is sick, or if there is no school for children (Rocha 2013). Therefore, fisherwomen's interests tend to be more place oriented than resource oriented, and they may not have time to fight for both, given that it takes 8-14 hours a day to harvest the shells and process the meat in addition to household activities. Furthermore, fishing communities have little infrastructure such as sewage and waste treatment (Nishida et al. 2008, Barletta and Costa 2009), putting at risk the coastal environments and filter feeders such as clams (Rehnstam-Holm and Hernroth 2005). The heterogeneity in fishing communities and fisher's levels of organization, literacy, and interest in participating in management creates a site-specific mosaic of favorable and unfavorable conditions for comanagement.

\section{The nature of government agencies}

In Brazil, fisheries occur within a complex regulatory framework involving environment, coastal governance, protected areas, traditional communities, and aquatic resources. From 1989 to 2007 IBAMA was in charge of forests, wildlife, fisheries, and protected areas management, including monitoring and law 
enforcement. After 2007 the protected area system moved to a new agency, Chico Mendes Institute for Biodiversity (ICMBio), and two years later the Ministry for Fisheries and Aquaculture (MPA) was created to plan and implement fisheries public policies. Presently IBAMA is still involved in fisheries monitoring and law enforcement as a partner to MPA.

IBAMA implemented the Pirajubaé MER very slowly: it took four years to legalize the first use plan, eight years to improve it, and six more years to readapt it. Top-down decisions and conflicting policies also allowed major estuary destruction and closed its fisheries, resulting in long-term public discrediting. Over 15 years, IBAMA negotiated only three sets of harvesting rules for Pirajubaé, despite the clear need for faster adaptation to changes at the local level. This slow response shows not only bureaucratic complexity but also how unimportant clams are considered to be. PoT, on the other hand, was already being implemented in the transition period when the MPA was created. There were also major delays in approval and project implementation because of political and government staff changes. Although difficulties were partially overcome by PoT coordination (showing openness to accommodate changes and local demands), a shortened implementation period jeopardized many expected project outcomes. Lack of commitment from local government was not overcome, allowing decisions to be made at higher levels. After PoT ended, key players engaged with comanagement in the federal government changed, making continuity difficult. Although stakeholders' participation in comanagement initiatives is possible under the Brazilian legal framework and initiatives are increasing, agencies generally lack the capacity, and sometimes the will, to successfully promote comanagement arrangements and share decisions.

\section{Steps toward comanagement}

Establishing a comanagement arrangement is a process that involves parties at different levels of power agreeing to specific rules and how to implement them in a particular time frame. With such complexity, comanagement should be conceived as an evolving relationship (Pinkerton 1992), a process of mutual adaptation between government policies and local institutions (Hara and Nielsen 2003), and a continuous "problem-solving in progress" (Carlsson and Berkes 2005). Pinkerton (1992) conceptualizes this process as containing five main steps: (1) adopting a negotiating posture, (2) conducting negotiations, (3) producing an agreement, (4) fully implementing the agreement, and (5) institutionalizing procedures. At Pirajubaé, IBAMA performed the first two steps toward the MER creation and clam harvest regulation, but took several years to finalize the third step, and failed in fully implementing the protected area as well as clam comanagement. Government inefficiency compromised the legitimacy of harvest regulation and fishers followed the rules minimally. At PoT, the three first steps were in part developed through creating issue networks of fishers, government agencies, research organizations, and NGOs (Pinkerton 1992) that brought parties together to discuss improvements in clam harvesting as well as fisher's well-being. CIDA, MPA, WFT, and governmental agencies formally agreed to implement PoT, and the project also promoted mobilization, at the state and national levels, for the recognition of illnesses due to the hard work of clam harvesting. However, there was insufficient time to consolidate the learning or institutionalize attitude changes regarding these issues.

\section{CLAM COMANAGEMENT IN BRAZIL: STEPS ACHIEVED AND BARRIERS STILL TO OVERCOME}

Pirajubaé and PoT involve clam management experiences developed under different conditions. The learning process at Pirajubaé started with a mollusk management project, magnified by the creation of the MER. In contrast, PoT was a product of a learning process after a decade of international partnerships, built upon experience acquired from other participatory initiatives.

The progression from Pirajubaé to PoT involved an enlargement in scope, scale, and number of parties. The Pirajubaé experience focused more on harvest management, and it is still the only place in Brazil with clam regulation. However, PoT went beyond harvest management because fishing communities' needs and priorities are more complex than simply resource extraction. Indeed, rights and duties related to both harvest and other management activities such as habitat protection and policy making at higher levels, build the path to successful comanagement (Pinkerton 2003). Furthermore, the scope should reflect local needs and not the requirements of donors or powerful organizations, whose priorities can cause goal displacement as happened in Africa (Hara and Nielsen 2003). PoT coordinators and funders were flexible enough to adjust the scope and include fisherwomen's social priorities. They also supported new initiatives and negotiated unexpected outcomes, showing flexibility and inclusiveness, two required qualities of governing systems (Jentoft 2007). Scope enlargement, flexibility, and inclusiveness were also recently implemented at Pirajubaé. These qualities allowed fishers not only to get more visibility, but also to influence decisions: health issues for fisherwomen in PoT and majority chairs in the Pirajubaé MER council.

The ideal scale for comanagement initiatives at a local level is large enough for meaningful planning and small enough for meaningful human interactions and consensus building (Pinkerton 2009b). Comanaging on a larger scale than community is a problem to be addressed (Nielsen et al. 2004). Projects at a regional scale may enable cooperation and combine multiple sources of data to create a better understanding of the system, besides the potential for complementary funding (Pinkerton 2009b). Berkes (2007) indicates the need to include a range of partners and networks to satisfy the variety of needs when integrating local communities' livelihoods into biodiversity conservation. The new participatory phase in Pirajubaé became possible after new investments brought new partners, aiming for participatory governance, and staff to MER. However, increase in scale and partners also increases logistical and costs complexity. As a regional scale and multiparty project, PoT's main difficulties were: (a) reconciling agendas and negotiating conflicts, (b) building stakeholders' capacity for knowledge sharing, and (c) communicating effectively with multiparty public audiences. Fishers' participation in activities beyond their community also had to be covered by the project, because families could not afford them. The process of selforganization involves costs in time and loss of short-term economic gains (Ostrom 2009), which families that depend on daily harvest for income cannot afford. Participation of fisherwomen beyond their communities was also challenging because of traditional family duties, a worldwide limitation (Weeratunge et al. 2010). 
Fishing communities along the coast have a range of levels of organization, literacy, and willingness to participate. Such heterogeneity can have multiple effects on building institutional sustainability for common pool resources (Agrawal 2002). Recognizing this is crucial for creating collective action in comanagement. In general clam fishers are poorly educated and organized, characteristics described as barriers in fisheries comanagement in Brazil (Diegues 2008, Kalikoski et al. 2009, Seixas et al. 2011). Under such conditions, it is necessary to begin with institution building, which is a costly and long-term process (Pomeroy and Berkes 1997). In the Pirajubaé and PoT initiatives harvesters were recognized as important stakeholders, and fisherwomen got visibility as main clam harvester in the Northeast. PoT had a strong approach to build local capacity, but not enough time to foster fishers' empowerment, while in Pirajubaé such an approach is fairly recent. Improved capacity and leadership are favorable factors in the nature of the community and the nature of the government agency, leading to increased legitimacy in the institutional arrangement between communities and government agencies. Future initiatives on clam comanagement still need to put significant effort into these issues because improvement in social capital building at the local level is needed before cooperative agreements and actions can emerge (Innes and Booher 1999).

Regarding community rights and duties related to fisheries management, fishers' rights existed de jure but several have not been implemented de facto. Beaches in Brazil are public areas under common use with free access; rights of exclusion in clam fisheries may happen only if the mollusk beds are located in protected areas. However, $36 \%$ of Brazilian protected areas are moderately effective and $51 \%$ have low effectiveness because of lack of human and financial resources, research and monitoring (IBAMA 2007). Therefore, although extractive reserves give traditional communities the rights to exclude others, these rights do not apply when the protected area is not fully implemented, weakening the comanagement initiatives.

In terms of governmental action, bureaucratic limitations, e.g., lack of personnel, funding, infrastructure, and research, caused later and shorter implementation for PoT and almost two decades of inconsequential MER implementation. Other problems were lack of continuity, lack of technical and/or ambivalent support, difficulties in sharing power, conflicting agendas among agencies, and lack of rule enforcement, all issues reflected in reviews discussing comanagement and marine protected areas in Brazil (Oviedo and Bursztyn 2004, Seixas 2006, Diegues 2008, Kalikoski et al. 2009, Seixas et al. 2011). According to Plummer and Fennell (2007), such difficulties relate to the temporary nature of political regimes, shifting policies and transient human resources: strong disrupting forces halting success in comanagement systems in general.

Pinkerton (1989) and Pomeroy and Berkes (1997) note that the benefits of comanagement become possible when there is one or a combination of three main goals: (a) community economic and social development, (b) decentralization of resource management decisions, or (c) conflict reduction through participation. In Pirajubaé, decentralization, conflict reduction, and participation became effective through the MER Management Council. PoT supported decentralization of decision making, economic feasibility studies of clam value chains, and the creation of fisher networks. However, there is no evidence that the cases provided real economic advantages for fisher families. Clam harvesting involves largely informal artisanal production (Macnaughton et al. 2010), and, to be successful, comanagement initiatives still have to pursue strategies to increase family income and improve the clam value chain.

\section{CONCLUSION}

Although stationary resources such as clams favor comanagement initiatives, success is a complex process. In successful comanagement arrangements, partners must understand each other and comprehend the system in which the clam harvest happens. They must share power, decide actions, adapt, and learn in an evolving process (Ratner et al. 2012). However, governing systems can be as diverse, complex, and dynamic as the systemto-be governed (Kooiman and Bavink 2005).

The experiences encompassing Venus clam comanagement in Brazil cover a period of two decades. Starting from a clear focus on harvesting rules at Pirajubaé, there has been an increase in the scope, scale, number of parties, management activities, and decision making level in PoT, a project with community development and equity as its main objectives. Institutional learning, flexibility, and institutional networking were fundamental in this process.

Strong barriers to comanagement in PoT and Pirajubaé were bureaucratic inertia, lack of continuity, lack of shell fisher organization, and government inability to fully implement arrangements. It is noteworthy, however, that both initiatives started the process of recognizing clam harvesters, especially women in the northeast coast, as important stakeholders. For the first time shell fisherwomen got visibility and influenced decisions on clam initiatives. Through their demands, a network to improve fisherwomen health was set up, recognizing that fisheries management is far more than managing stocks. However, making room for comanagement initiatives in shell fisherwomen's lives is challenging. Clam harvest and household duties are overlapping full-time jobs, and power relationships within households also interfere. Positive results in seed production were also achieved, building the potential path of replenishing mollusk beds in overexploited clam areas. Major challenges are building local capacity for fishers and government, better implementation for protected areas, and improvement in families' income and the clam value chains.

We may be far from the successful comanagement of clams in Brazil, considering the difficulties already discussed, but this achievement is only possible if we review past initiatives, share the experience, and have a vision for the future. We hope future clam comanagement initiatives learn from past Brazilian efforts discussed here. MERs favor comanagement, but their creation does not imply real participation unless they are fully implemented. Arrangements such as PoT are also feasible and promote participation, but they risk lack of continuity. In this process, greater government involvement and willingness to share power, having fisher families as core parties (considering fisherwomen as the centerpiece), inclusion of management activities that go beyond harvest management, and tangible benefits for fisher families are critical to the long-term success of clam comanagement. Only then will such arrangements promote sustainability for Venus clams as well as shell fisher families. 
Responses to this article can be read online at:

http://www.ecologyandsociety.org/issues/responses. php/7095

\section{Acknowledgments:}

We would like to thank WFT coordinators Joachim Carolsfeld and Alison Macnaughton for their support and for reviewing the manuscript. LMR also thanks shell fisher families at PoT, Prof. Paulo Pezzuto for providing key references, the Federal University of Rio Grande do Norte and the Ministry of Education (CAPES) for doctoral fellowships. Part of this paper was developed while LMR was a visiting researcher at Simon Fraser University (CAPES-BEX 9018/11-5).

\section{LITERATURE CITED}

Agrawal, A. 2002. Common resources and institutional sustainability. Pages 41-85 in E. Ostrom, T. Dietz, N. Doisak, P. C. Stern, S. Stonich, and E. U. Weber, editors. The drama of the commons. National Academy Press, Washington, D.C., USA.

Articulação Nacional de Pescadoras. 2006. Carta aberta de Fundação. C. Faustino and S. Nogueira, editors. Proceedings of the "I Encontro da Articulação de Mulheres Pescadoras do Ceará: na pesca e na luta mulheres construindo direitos", 27-29th November 2010, Ceará, Brazil. Instituto Terramar, Fortaleza, Ceará, Brazil.

Barletta, M., and M. F. Costa. 2009. Living and non-living resources exploitation in a tropical semi-arid estuary. Journal of Coastal Research SI 56:371-375. [online] URL: http://www.cerfjcr.org/images/stories/371.375 M.Barletta ICS2009.pdf

Berkes, F. 2007. Community-based conservation in a globalized world. Proceedings of the National Academy of Sciences of United States of America 104:15188-15193. http://dx.doi.org/10.1073/ pnas.0702098104

Brasil, Agência Brasileira de Cooperação ABC/MRE. 2007. Promoção da eqüidade e da cidadania através do desenvolvimento da maricultura e da co-gestão dos recursos costeiros em comunidades costeiras do nordeste do Brasil. ABC/MRE, Brasília, Brazil.

Carlsson, L., and F. Berkes. 2005. Co-management: concepts and methodological implications. Journal of Environmental Management 75:65-76. http://dx.doi.org/10.1016/j.jenvman.2004.11.008

Castilla, J. C., and O. Defeo. 2001. Latin-American benthic shellfisheries: emphasis on co-management and experimental practices. Reviews in Fish Biology and Fisheries 11:1-30. http://dx. doi.org/10.1023/A:1014235924952

de Castro, F., and D. G. McGrath. 2003. Moving toward sustainability in the local management of floodplain lake fisheries in the Brazilian Amazon. Human Organization 62:123-133.

Defeo, O., and J. C. Castilla. 2005. More than one bag for the world fishery crisis and keys for co-management successes in selected artisanal Latin American shellfisheries. Reviews in Fish Biology and Fisheries 15:265-283. http://dx.doi.org/10.1007/ s11160-005-4865-0
Diegues, A. C. 2008. Marine protected areas and artisanal fisheries in Brazil. Samudra Monograph. International Collective in Support of Fishworkers, Chennai, India. [online] URL: http:// www.icsf.net/images/monographs/pdf/english/issue_99/99_all.pdf

Faustino, C. 2008. Sentido e rumos da participação política das mulheres na zona costeira. Pages 1-3 in Proceedings of the Taller Latinoamericano de La Pesca Artesanal: consolidar y garantizar el acceso y los derechos de uso de la pesca artesanal (Punta de Tralca, 4-8 August 2008). Colectivo Internacional de Apoyo a los Pescadores Artesanales (ICSFCIAPA), CeDePesca, Ecocéanos y Confederación Nacional de Pescadores Artesanales de Chile (CONAPACH), Valparaíso, Chile.

Fearnside, P. M. 1989. Extractive reserves in Brazilian Amazonia: an opportunity to maintain tropical rain forest under sustainable use. BioScience 39:387-393. [online] URL: http://www.jstor.org/ $\underline{\text { stable/1311068 }}$

Food and Agriculture Organizations of the United Nations (FAO). 2007. The state of world fisheries and aquaculture 2006. FAO, Rome, Italy.

Frangoudes, K., B. Marugán-Pintos, and J. J. Pascual-Fernández. 2008. From open access to co-governance and conservation: the case of women shellfish collectors in Galicia (Spain). Marine Policy 32:223-232. http://dx.doi.org/10.1016/j.marpol.2007.09.007

Goeschl, T., and D. C. Igliori. 2004. Reconciling conservation and development: a dynamic hotelling model of extractive reserves. Land Economics 80:340-354. [online] URL: http://www.jstor.org/ stable/3654725

Hara, M., and J. R. Nielsen. 2003. Experiences with fisheries comanagement in Africa. Pages 81-97 in D. C. Wilson, R. J. Nielsen, and P. Degnbol, editors. The fisheries co-management experience: accomplishments, challenges and prospects. Kluwer Academic, Dordrecht, The Netherlands. http://dx.doi.org/10.1007/978-94-017-3323-6 6

Innes, J. E., and D. E. Booher. 1999. Consensus building and complex adaptive systems. Journal of the American Planning Association 65:412-423. http://dx.doi.org/10.1080/01944369908976071

Instituto Brasileiro do Meio Ambiente e dos Recursos Naturais Renováveis (IBAMA). 1996. Portaria $N^{o} 78$ de 30/09/1996 - Plano de Utilização da Reserva Extrativista Marinha do Pirajubaé. IBAMA, Brasília, Brazil.

Instituto Brasileiro do Meio Ambiente e dos Recursos Naturais Renováveis (IBAMA). 2003. Relatório da II Reunião de Pesquisa e Ordenamento sobre o Berbigão (Anomalocardia brasiliana) explotado na Reserva Extrativista Marinha do Pirajubaé (Florianópolis - SC). IBAMA/CEPSUL, Itajai, SC, Brazil.

Instituto Brasileiro do Meio Ambiente e dos Recursos Naturais Renováveis (IBAMA). 2004. Instrução Normativa $N^{o} 19$ de 09/03/2004. IBAMA, Brasília, Brazil.

Instituto Brasileiro do Meio Ambiente e dos Recursos Naturais Renováveis (IBAMA). 2005. Instrução Normativa $N^{o} 81$ de 28/12/2005. IBAMA, Brasília, Brazil.

Instituto Brasileiro do Meio Ambiente e dos Recursos Naturais Renováveis (IBAMA). 2007. Efetividade de gestão das unidades de conservação federais do Brasil. IBAMA, WWF-Brasil, Brasília, Brazil. 
Jentoft, S. 2007. Limits of governability: institutional implications for fisheries and coastal governance. Marine Policy 31:360-370. http://dx.doi.org/10.1016/j.marpol.2006.11.003

Jentoft, S., and R. Chuenpagdee. 2009. Fisheries and coastal governance as a wicked problem. Marine Policy 33:553-560. http://dx.doi.org/10.1016/j.marpol.2008.12.002

Kalikoski, D. C., C. S. Seixas, and T. Almudi. 2009. Gestão compartilhada e comunitária da pesca no Brasil: avanços e desafios. Ambiente \& Sociedade 12:151-172. http://dx.doi. org/10.1590/S1414-753X2009000100011

Kooiman, J., and M. Bavink. 2005. The governance perspective. Pages 11-24 in J. Kooiman, M. Bavink, S. Jentoft, and R. Pullin, editors. Fish for life: interactive governance for fisheries. Amsterdam University Press, Amsterdam, The Netherlands.

Lopes, P. F. M., E. M. Rosa, S. V Salyvonchyk, V. Nora, and A. Begossi. 2013. Suggestions for fixing top-down coastal fisheries management through participatory approaches. Marine Policy 40:100-110. http://dx.doi.org/10.1016/j.marpol.2012.12.033

Lopes, P. F. M., R. A. M. Silvano, and A. Begossi. 2011. Extractive and sustainable development reserves in Brazil: resilient alternatives to fisheries? Journal of Environmental Planning and Management 54:421-443. http://dx.doi.org/10.1080/09640568.2010.508687

Macnaughton, A., L. M. da Rocha, J. M. Wojciechowsk, and J. Carolsfeld. 2010. Tools for understanding the complexities of small-scale coastal fisheries economies in Northeastern Brazil: participatory value-chain mapping and economic feasibility studies. ID paper 536 in A. L. Shriver, editor. Proceedings of the IIFET- International Institute of Fisheries Economic and Trade, 13-17 July 2010, Montpellier, France. International Institute of Fisheries Economics \& Trade, Corvallis, Oregon, USA.

Monti, D., L. Frenkiel, and M. Moueza. 1991. Demography and growth of Anomalocardia brasiliana (Gmelin) (Bivalvia: Veneridae) in a mangrove, in Guadeloupe (French West Indies). Journal of Molluscan Studies 57:249-257. http://dx.doi. org/10.1093/mollus/57.2.249

Moueza, M., O. Gros, and L. Frenkiel. 1999. Embryonic, larval and post larval development of the tropical clam Anomalocardia brasiliana (Bivalvia, Veneridae). Journal of Molluscan Studies 65:73-88. [online] URL: http://mollus.oxfordjournals.org/ content/65/1/73.full.pdf

Nielsen, J. R., P. Degnbol, K. K. Viswanathan, M. Ahmed, M. Hara, and N. M. R. Abdullah. 2004. Fisheries co-management an institutional innovation? Lessons from South East Asia and Southern Africa. Marine Policy 28:151-160. http://dx.doi. org/10.1016/S0308-597X(03)00083-6

Nishida, A. K., N. Nordi, and R. R. N. Alves. 2004. Abordagem etnoecológica da coleta de moluscos no litoral Paraibano. Tropical Oceanography 32:53-68. http://www.revista.ufpe.br/ tropicaloceanography/artigos completos resumos t d/32 2004_1 nishida. pdf

Nishida, A. K., N. Nordi, and R. R. N. Alves. 2006. Mollusc gathering in Northeast Brazil: an ethnoecological approach. Human Ecology 34:133-145. http://dx.doi.org/10.1007/s10745-005-9005-
Nishida, A. K., N. Nordi, and R. R. N. Alves. 2008. Aspectos socioeconômicos dos catadores de moluscos do litoral paraibano, Nordeste do Brasil. Revista de Biologia e Ciências da Terra $8: 207-215$.

Ostrom, E. 2009. A general framework for analyzing sustainability of social-ecological systems. Science 325:419-22. http://dx.doi.org/10.1126/science.1172133

Oviedo, A., and M. Bursztyn. 2004. Challenges for the comanagement of fisheries in the Brazilian Amazon. Proceedings of the Workshop in Political Theory and Policy Analysis, Workshop on the Workshop 3. Indiana University, Bloomington, Indiana, USA. [online] URL: http://www.indiana.edu/ wow3/papers/ wow3 oviedo.pdf

Pezzuto, P. R., and A. M. Echternacht. 1999. Avaliação de impactos da construção da Via Expressa SC-Sul sobre o berbigão Anomalocardia brasiliana (Gmelin, 1791) (Mollusca: Pelecypoda) na Reserva Extrativista Marinha do Pirajubaé (Florianópolis, Brasil). Atlântica 21:105-119. [online] URL: http://siaiacad04. univali.br/download/publicacoes/1999/anomalocardia impact assessment 1999.pdf

Pezzuto, P. R., C. Schio, and T. C. M. Almeida. 2010. Efficiency and selectivity of the Anomalocardia brasiliana (Mollusca: Veneridae) hand dredge used in Southern Brazil. Journal of the Marine Biological Association of the United Kingdom 90:1455 -1464. http://dx.doi.org/10.1017/S0025315410000317

Pinkerton, E. 1989. Attaining better fisheries management through co-management: prospects, problems, and propositions. Pages 3-33 in E. Pinkerton, editor. Co-operative management of local fishers: new directions for improved management and community development. University of British Columbia, Vancouver, British Columbia, Canada.

Pinkerton, E. 1992. Translating legal rights into management practice: overcoming barriers to the exercise of co-management. Human Organization 51:330-341.

Pinkerton, E. 2003. Toward specificity in complexity: understanding co-management social science. Pages 61-77 in D. K. Wilson, J. R. Nielsen, and P. Dengbol, editors. The fisheries co-management experience: accomplishments, challenges and prospects. Kluwer Academic, Dordrecht, The Netherlands. http:// dx.doi.org/10.1007/978-94-017-3323-6 5

Pinkerton, E. 2009a. Coastal marine systems: conserving fish and sustaining community livelihoods with co-management. Pages 241-257 in F. S. Chapin, G. P. Kofinas, and C. Folke, editors. Principles of ecosystem stewardship: resilience-based natural resource management in a changing world. Springer, New York, New York, USA. http://dx.doi.org/10.1007/978-0-387-73033-2_11

Pinkerton, E. 2009b. Partnerships in management. Pages 283-300 in K. L. Cochrane and S. M. Garcia, editors. A fishery manager's guidebook. Second edition. FAO and Wiley-Blackwell, Rome, Italy. http://dx.doi.org/10.1002/9781444316315.ch11

Pinkerton, E., and L. John. 2008. Creating local management legitimacy. Marine Policy 32:680-691. http://dx.doi.org/10.1016/ j.marpol.2007.12.005 
Pinkerton, E., and M. Weinstein. 1995. Fisheries that work: sustainability through community-based management. Technical Report. The David Suzuki Foundation, Vancouver, British Columbia, Canada.

Plummer, R., and D. Fennell. 2007. Exploring co-management theory: prospects for sociobiology and reciprocal altruism. Journal of Environmental Management 85:944-55. http://dx.doi. org/10.1016/j.jenvman.2006.11.003

Pomeroy, R. S., and F. Berkes. 1997. Two to tango: the role of government in fisheries co-management. Marine Policy 21:465-480. http://dx.doi.org/10.1016/S0308-597X(97)00017-1

Prates, A. P., and D. Blanc. 2007. Áreas Aquáticas Protegidas como instrumento de gestão pesqueira. Ministerio do Meio Ambiente, Brasília, Brazil.

Ratner, B. D., E. J. V Oh, and R. S. Pomeroy. 2012. Navigating change: second-generation challenges of small-scale fisheries comanagement in the Philippines and Vietnam. Journal of Environmental Management 107:131-139. http://dx.doi.org/10.1016/ j.jenvman.2012.04.014

Rehnstam-Holm, A.-S., and B. Hernroth. 2005. Shellfish and public health: a Swedish perspective. Ambio 34:139-144. [online] URL: http://www.jstor.org/stable/4315572

Rocha, L. M. 2013. Ecologia Humana e Manejo Participativo da Pesca de búzio Anomalocardia brasiliana (Gmelin,1791)(Bivalvia: Veneridae) na Reserva de Desenvolvimento Sustentável Estadual Ponta do Tubarão ( $R N)$. Dissertation. Universidade Federal do Rio Grande do Norte, Natal, Rio Grande do Norte, Brazil.

Rocha, L. M., and S. Jacobson. 1998. Partnerships for conservation: protected areas and nongovernmental organizations in Brazil. Wildlife Society Bulletin 26:937-946. [online] URL: http://www.jstor.org/stable/3783573

Seixas, C. S. 2006. Barriers to local-level ecosystem assessment and participatory management in Brazil. Pages 255-274 in W. E. Al Reid, editor. Bridging scales and knowledge systems: concepts and applications in ecosystem assessments. Island Press, Washington, USA.

Seixas, C. S., and D. C. Kalikoski. 2009. Gestão participativa da pesca no Brasil: levantamento das iniciativas e documentação dos processos. Desenvolvimento e Meio Ambiente 20:119-139. http:// dx.doi.org/10.5380/dma.v20i0.12729

Seixas, C. S., D. C. Kalikoski, T. Almudi, V. S. Batista, A. L. Costa, H. L. Diogo, B. P. Ferreira, C. R. T. Futemma, R. L. Moura, M. Ruffino, R. de Salles, and A. P. G. Thé. 2011. Gestão compartilhada do uso de recursos pesqueiros no Brasil: elementos para um programa nacional. Ambiente \& Sociedade XIV:23-44.

Silva, L. G., editor. 1988. Os pescadores na história do Brasil: colônia e império. Vozes, Petrópolis, Brazil.

Silva-Cavalcanti, J. S., and M. F. Costa. 2009. Fisheries in protected and non-protected areas: is it different? The case of Anomalocardia brasiliana at tropical estuaries of Northeast Brazil. Journal of Coastal Research ICS2009:1454-1458.
Souza, D. S. 2007. Caracterização da pescaria do berbigão Anomalocardiabrasiliana (Gmelin, 1791) (Mollusca: Bivalvia) na Reserva Extrativista Marinha do Piraubaé (Florianópolis/SC): subsídios para o manejo. Thesis. Universidade do Vale do Itajaí, Itajaí, Paraná, Brazil.

Spínola, J. L. 2011. Participação e deliberação na Resex Marinha do Pirajubaé. Dissertation. Universidade Federal do Paraná, Curitiba, Paraná, Brazil.

Vasconcellos, M., A. C. Diegues, and R. R. de Sales. 2007. Limites e Possibilidades na Gestão da Pesca Artesanal Costeira. Pages 15-84 in A. L. Costa, editor. Nas redes da pesca artesanal. PNUD/ IBAMA, Brasília, Brazil.

Vasconcellos, M., A. C. Diegues, and D. C. Kalikoski. 2011. Coastal fisheries of Brazil. Pages 73-116 in S. Salas, R. Chuenpagdee, A. Charles, and J. C. Seijo, editors. Coastal fisheries of Latin America and the Caribbean. Technical Paper 544. FAO, Rome, Italy.

Vizinho, S. C., and M. M. P. Tognella-de-Rosa. 2010. Análise Sócio-econômica e Cultural da comunidade pesqueira do Pirajubaé (Baía Sul - Florianópolis - Santa Catarina - Brasil): uma ferramenta para o gerenciamento costeiro integrado. Revista de Gestão Costeira Integrada 8:1-9.

von Behr, M. 1995. Descrição da Reserva Extrativista Marinha do Pirajubaé. Pages 77-80 in J. R. Murrieta and R. P. Rueda, editors. Reservas Extrativistas. UICN, Gland, Switzerland.

Weeratunge, N., K. A. Snyder, and C. P. Sze. 2010. Gleaner, fisher, trader, processor: understanding gendered employment in fisheries and aquaculture. Fish and Fisheries 11:405-420. http:// dx.doi.org/10.1111/j.1467-2979.2010.00368.x

World Fisheries Trust (WFT) and Ministério da Pesca e Aquacultura (MPA). 2011. Desenvolvimento de Comunidades Costeiras no Nordeste do Brasil - Projeto Gente da Maré, Relatório Final, abril de 2008 a março de 2010. WFT/MPA, Brasília, Brazil. 